VERTAISARVIOITU

KOLLEGIALT GRANSKAD

PEER-REVIEWED

www.tsv.fi/tunnus

\title{
POHJOISSAAMEN ADNOMINAALISET DEMONSTRATIIVIPRONOMINIT NUORTEN RADIOKESKUSTELUISSA
}

\section{Outi Guttorm, Sámi allaskuvla ja Oulun yliopisto}

\begin{abstract}
Tarkastelen tässä artikkelissa pohjoissaamen demonstratiivipronominien, erityisesti adnominaalisten pronominien dát 'tämä' ja diet 'se (siinä)' endoforista käyttöä nuorten puhekielessä. Tarkoitukseni on selvittää miten pronomineja käytetään ja mihin niillä viitataan nuorten radiokeskusteluissa, joissa viittaaminen näköpiirissä oleviin konkreettisiin tarkoitteisiin ei ole ensisijaista. Pohdin myös pronominien keskinäisiä eroja ja tehtäviä keskustelussa. Tutkimusaineisto on Norjan yleisradioyhtiö NRK:n saamenkielisistä nuortenohjelmista. Siinä endoforisina pronomineina esiintyvät dat 'se', diet 'se (siinä)' ja dát 'tämä'. Selkeästi yleisin anaforinen pronomini on dat. Radiokeskusteluissa diet-pronominilla viitataan erityisesti johonkin, josta on edellä kuultu. Sillä viitataan myös tarkoitteeseen, joka esiintyy toisessa yhteydessä, tai keskustelukumppanin mainitsemaan asiaan. Dát-pronomini puolestaan nostaa tarkoitteen erityiseen fokukseen. Se on myös yleisin kataforinen pronomini. Tutkimus täydentää ja tarkentaa kielioppien aiempia näkemyksiä pohjoissaamen demonstratiivien käytöstä ja merkityksestä.
\end{abstract}

Avainsanat: demonstratiivipronomini, pohjoissaame, puhekieli, saamen kieli

\section{JOHDANTO}

Pohjoissaame kuuluu saamelaiskieliin, joita on yhteensä yhdeksän, ja pohjoissaame on niistä puhuma-alueeltaan ja -määrältään suurin. Sammallahden (1998) mukaan pohjoissaamen puhujista noin 10000 asuu Norjassa,

Kirjoittajan yhteystiedot:

Outi Guttorm

outi.guttorm@samiskhs.no noin 2000 Suomessa ja noin 5000 Ruotsissa. Arvio puhujien määristä voi vaihdella eri lähteissä, koska Ruotsista ja Norjasta ei ole virallisia tilastoja.

Pohjoissaamessa on viisi - tai Nielsenin (1979, s. 125-126) mukaan jopa kuusi - demonstratiivipronominia (dat, dát, diet, duot, dot ja dut), joita on kuvattu perinteisesti sen pohjalta miten kaukana tai lähellä viittauksen kohde sijaitsee puhujaan tai kuulijaan nähden. Pronomini dát ilmaisee, että tarkoite sijaitsee lähellä puhujaa, pronomini diet puolestaan, että tarkoite on lähempänä kuulijaa. Pronominit duot ja dot viittaavat tarkoitteisiin, jotka eivät ole puhujan eivätkä kuulijan 
lähellä. Dot viittaa kauemmaksi kuin duot, ja harvinainen dut vielä kauemmaksi kuin edelliset. Dat-pronominin deiktinen merkitys on vähäinen, ja Sammallahden (1998, s. 117) mukaan sen käyttö on rajoittunut anaforisiin tapauksiin.

Saamen demonstratiiveja on siis kuvattu lähinnä niiden deiktisen merkityksen ja eksoforisen käytön perusteella, endoforisen käytön tarkastelu on jäänyt vähemmälle. Tarkastelenkin tässä artikkelissa erityisesti adnominaalisten dát- ja diet-pronominien endoforista käyttöä puhekielessä. Eksoforisen käytön rajaan tutkimuksen ulkopuolelle. Diesselin mukaan (1999, s. 93-114) eksoforisessa käytössä demonstratiivit kiinnittävät kuulijan huomion tarkoitteisiin (esineisiin, ihmisiin tai paikkoihin), jotka voidaan havaita keskustelutilanteessa. Endoforisessa käytössä puolestaan viitataan keskustelun sisäisiin tarkoitteisiin. Endoforinen käyttö voidaan jakaa edelleen anaforiseen, diskurssideiktiseen ja rekognitionaaliseen käyttöön. Anaforiset demonstratiivit viittaavat diskurssissa aiemmin mainittuihin referentteihin ja diskurssideiktiset demonstratiivit taas laajempaan keskustelun osaan. Rekognitionaalisessa käytössä demonstratiivin käyttö implikoi, että puhuja ja kuulija tunnistavat tarkoitteen yhteisen kokemuksensa perusteella. Tässä tutkimuksessa niputan anaforisen ja diskurssideiktisen käytön yhteen.

Tarkoitukseni on selvittää miten pronomineja käytetään ja mihin niillä viitataan nuorten radiokeskusteluissa, joissa viittaaminen näköpiirissä oleviin konkreettisiin tarkoitteisiin ei ole ensisijaista. Keskityn demonstratiivien adnominaalisen käytön tarkasteluun, koska minua kiinnostaa pronominien mahdollinen käyttö myös definiittisenä artikkelina, jota olen tutkinut toisaalla (Guttorm, 2015; Kilpimaa, 2002). Tarkastelen saamen pronomineja lyhyesti myös kielitypologisesta näkökulmasta sekä pohdin niiden keskinäi- siä tehtäviä ja merkityseroja. Teorian osalta tukeudun pitkälti saksalaiseen Holger Diesseliin (1999, 2006, 2012, 2013), joka on tutkinut eri kielten demonstratiivien muotoja, tehtäviä ja kieliopillistumista kielitypologisesta näkökulmasta, mutta hyödynnän myös suomalaista pronominitutkimusta (Etelämäki, 2006; Larjavaara, 1990; Laury, 1997; Priiki, 2017). Tutkimukseni tavoitteena on täydentää ja tarkentaa kielioppien tietoja saamen demonstratiivien käytöstä ja merkityksestä. Saamella tarkoitan tässä artikkelissa pohjoissaamen kieltä.

Seuraavaksi esittelen lyhyesti aiheeseen liittyvää aiempaa tutkimusta ja sen jälkeen saamen kielen demonstratiivijärjestelmää. Ennen kuin tarkastelen lähemmin saamen adnominaalisten demonstratiivipronominien käyttöä, esittelen tutkimusaineiston. Lopuksi pohdin tutkimukseni tuloksia.

\section{AIEMPI TUTKIMUS JA TEOREETTINEN TAUSTA}

Demonstratiivien eksoforinen ja endoforinen käyttö ovat olleet useiden tutkimusten kohteena (esim. Fillmore, 1997; Halliday \& Hasan, 1976; Himmelmann, 1996, 1997; Levinson, 1983; Lyons, 1977). Termeistä eksoforinen ja endoforinen käytetään myös käsiteparia deiktinen ja anaforinen (VISK, § 1427). Hallidayn ja Hasanin (1976) tavoin Diessel (1999, s. 93-109) käyttää termejä eksoforinen ja endoforinen. Eksoforisten demonstratiivien tehtävä on kiinnittää kuulijan huomio puhetilanteessa oleviin tarkoitteisiin, esineisiin, ihmisiin tai paikkoihin. Ne ovat tilannesiteisiä, sillä tarkoitteen tunnistaminen perustuu meneillään olevaan tilanteeseen. Endoforiset pronominit taas ovat diskurssisiteisiä. Niistä anaforisten demonstratiivien tehtävä on jäljittää keskustelun kannalta keskeisiä ja tärkeitä referenttejä. Diskurssideiktiset demonstratiivit viittaavat yksittäistä 
referenttiä laajempaan osaan keskustelussa. Diskurssideiktiset demonstratiivit voivat olla sekä anaforisia että kataforisia eli viitata keskustelussa sekä taakse- että eteenpäin, kun taas anaforiset demonstratiivit viittaavat ainoastaan aiemmin mainittuihin tarkoitteisiin. Rekognitionaalisessa käytössä demonstratiivi ilmaisee, että referentti on tuttu sekä puhujalle että kuulijalle heidän yhteisen kokemuksensa tai tietonsa pohjalta.

Muista kielistä poiketen saamen demonstratiiveja ei ole juurikaan tutkittu. Niitä koskevat tiedot pohjautuvat suurelta osin kieliopeissa esitettyihin kuvauksiin, joissa keskeisellä sijalla ovat juuri spatiaaliset ominaisuudet. Itse olen aloittanut demonstratiivipronominien tutkimisen pro gradu -tutkielmassani, jossa definiittisyyteen liittyen tarkastelin tekstimateriaalin pohjalta, mihin dat-tarkenteisen nominilausekkeen identifioitavuus voi perustua (Kilpimaa, 2002). Olen myös tarkastellut adnominaalisten demonstratiivilausekkeiden endoforista ja eksoforista käyttöä kertomakirjallisessa tekstissä (Guttorm, 2009). Viimeksi olen pohtinut dat-pronominin statusta definiittisenä artikkelina sen esiintymiskontekstien pohjalta puhekielessä (Guttorm, 2015). Näiden tutkimusten lisäksi Helmi Länsman (2009) on pro gradu -työssään tutkinut tekstilingvistiikan keinoin demonstratiivipronomineilla viittaamista kaunokirjallisissa teksteissä. Vesa Guttorm (1994) puolestaan on tarkastellut dat-pronominin esiintymistä relatiivilauseiden ja muutamien muiden sivulauseiden yhteydessä.

Saameen verrattuna suomen ja viron demonstratiiveja on tutkittu paljonkin. Matti Larjavaara $(1985,1986,1990)$ on tutkinut suomen ja itämerensuomalaisten kielten demonstratiiveja ja deiksistä laajasti. Kun aiemmin demonstratiiveja on tutkittu pitkälti keksittyjen esimerkkien pohjalta, niin viime vuosikymmeninä väitöskirjatutkimusten aineistoina ovat olleet autenttiset puhe- ja keskustelumateriaalit. Ritva Laury (1997) on tutkinut $s e$-pronominin kehittymistä määräiseksi artikkeliksi, ja samalla kuvannut suomen pronomineja havaintopiirien avulla. Eeva-Leena Seppänen (1998) on tarkastellut pronomineja tämä, tuo, se ja hän viittaamassa keskusteluun osallistujaan. Marja Etelämäki (2006) on tutkinut erityisesti pronominia tämä viittaamassa ei-henkilöreferentteihin. Hän käsittelee myös se- ja tuo-pronomineja. Etelämäki kuvaa pronomineja kolmen ulottuvuuden avulla: referentiaalisen, indeksisen ja relationaalisen. Referentiaalinen ulottuvuus tarkoittaa sitä, onko tarkoite riittävän tunnettu tilanteen tarpeisiin vai ei. Indeksinen ulottuvuus puolestaan sitä, että pronominit implikoivat taustan symmetriaa tai jäsentävät taustan epäsymmetriseksi. Kun tausta on symmetrinen, osallistujilla on riittävän yhteinen ymmärrys siitä toiminnasta, joka on viittauksen taustana. Relationaalinen ulottuvuus tarkoittaa suhdetta, jonka demonstratiiviviittaus virittää tarkoitteen ja taustan välille. Etelämäen uutta näkökulmaa olisi mielenkiintoista kokeilla myös saamen demonstratiivien kuvauksessa. Uusin suomen pronomineja käsittelevä tutkimus on Katri Priikin (2017) väitöskirja se-, tää-, toi- ja hänpronomineista viittauksissa henkilöön, joka ei ole keskustelutilanteessa läsnä.

Myös viron kielen demonstratiivien tutkimus on ollut vilkasta. Viron demonstratiiveihin laajasti perehtynyt Renate Pajusalu (2015) on viimeksi tarkastellut muutoksia võrun demonstratiivijärjestelmässä ja persoonapronominien käytössä. Võrun demonstratiiveja on tutkinut myös Liisa Tammekänd (2015). Maria Reile (2015) puolestaan on koetilanteen pohjalta tutkinut missä määrin etäisyys vaikuttaa eksoforisen demonstratiivin valintaan virossa. Nyt käsillä oleva tutkimus liittyy luontevasti osaksi tätä suomalais-ugrilaisten kielten demonstratiivien tutkimusta. 


\section{SAAMEN DEMONSTRATIIVIJÄRJESTELMÄ}

Saamessa on erittäin rikas ja laaja demonstratiivijärjestelmä, johon kuuluu viisi-kuusi demonstratiivipronominia: dát 'tämä, duot 'tuo', dot 'tuo (kauempana kuin duot)', diet 'se (lähellä kuulijaa)' ja anaforinen dat 'se' (esim. Nickel \& Sammallahti, 2011, s. 117). Muista kieliopeista poiketen Nielsen (1979, s. 126) mainitsee lisäksi Kaarasjoen ja Pulmangin murteesta vielä pronominin $d u t$, joka viittaa vielä kauemmaksi kuin duot ja dot.

Nämä, samoin kuin suomen demonstratiivipronominit, ovat palautettavissa uralilaisen kantakielen kolmijäseniseen demonstratiivijärjestelmään. Siinä oletetaan olleen lähel- le viittaava proksimaalinen demonstratiivi (vrt. saamen dát, suomen tämä) ja kauemmaksi viittaava distaalinen demonstratiivi (vrt. saamen duot, suomen tuo) sekä kolmas demonstratiivi, jonka tehtävä ei ole täysin selvä. Se on voinut olla anaforinen tai kuulijan lähelle viittaava pronomini (vrt. saamen dat ja diet, suomen $s e$ ) tai sitten se on voinut toimia näissä molemmissa tehtävissä (ks. Abondolo, 1998, s. 25-27). Saamessa on oma pronomininsa sekä anaforiseen käyttöön (dat) että kuulijan lähelle viittaamiseen (diet), vaikkakaan työnjako näiden välillä ei ole kaikissa käyttökonteksteissa täysin selkeä. Abondolo (1998, s. 27) esittää pohjoissaamen demonstratiivisysteemin seuraavasti:

Taulukko 1. Pohjoissaamen demonstratiivipronominit (Abondolo 1998).

\begin{tabular}{|l|l|l|l|l|l|}
\hline Anaforinen & \multicolumn{4}{l|}{ Demonstrativinen } \\
\hline & \multicolumn{4}{ll}{} & \multicolumn{2}{l|}{} \\
\hline & $\begin{array}{l}\text { Lähellä } \\
\text { puhujaa }\end{array}$ & $\begin{array}{l}\text { Lähellä } \\
\text { kuulijaa }\end{array}$ & Etäällä & Etäämpänä & $\begin{array}{l}\text { Vielä } \\
\text { etäämpänä }\end{array}$ \\
\hline dat & dát & diet & duot & dot & dut \\
\hline
\end{tabular}

Typologisesta näkökulmasta katsottuna saamen demonstratiivijärjestelmä on melko harvinainen. Tavallisimmin kielissä on kaksi tai kolme demonstratiivijäsentä, jotka ilmentävät tarkoitteen etäisyyttä deiktisestä keskuksesta kuten esimerkiksi suomen tämä, tuo ja se. Saamessa näitä jäseniä on aktiivisessa käytössä neljä: dát, diet, duot ja dot. Jos näiden lisäksi laskee vielä Nielsenin mainitseman harvinaisen $d u t$-pronominin, niin jäseniä on viisi. (Dat on lähinnä anaforinen.) Diessel (2013) on löytänyt maailmanlaajuisesta 234 kielen korpuksesta 127 kieltä, joissa on kaksi deiktistä jäsentä ja 88 kieltä, joissa on kolme deiktistä jäsentä. Kahdessatoista kielessä on enemmän kuin kolme jäsentä. Nämä luvut koskevat adnominaalisia demonstratiiveja, sillä joissakin kielissä itsenäiset ja adnominaaliset demonstratiivit eivät ilmaise samoja etäisyyksiä. Se on kuitenkin suhteellisen harvinaista. Jos näin sattuu olemaan, niin itsenäiset demonstratiivit ilmaisevat tavallisesti useampia etäisyyksiä kuin adnominaaliset. Esimerkiksi polynesialaisessa tongan kielessä on kaksi adnominaalista demonstratiivia, jotka ilmaisevat etäisyyttä lähelle ja kauas, kun taas itsenäiset demonstratiivijäsenet erottavat tarkoitteet, jotka ovat lähellä puhujaa, lähellä kuulijaa ja kaukana sekä puhujasta että kuulijasta. Lisäksi tongassa on neutraali demonstratiivi, jota käytetään ainoastaan itsenäisenä. 
Diessel (2012, s. 13-14) on myös havainnut, että kielissä, joissa on useampi kuin kolme deiktistä jäsentä, on tavallisesti erityinen ilmaisu lähellä kuulijaa olevia tarkoitteita ja paikkoja varten. Näin näyttää olevan myös saamessa. Diesselin mukaan tällaisissa kielissä deiktinen keskus hahmottuu kahdella eri tavalla. Hän ottaa esimerkiksi afroaasialaisen kielikunnan tšadilaiseen kieliryhmään kuuluvan hausan, jossa puhujan ja toisaalta kuulijan lähelle viittaavat demonstratiivit tulkitaan suhteessa alueeseen, jota määrittää ainoastaan puhujan sijainti (saamessa dát ja diet). Nämä ilmaisut siis jättävät kuulijan deiktisen keskuksen ulkopuolelle. Kaksi distaalista jäsentä (saamessa duot ja dot) puolestaan tulkitaan suhteessa keskusteluun osallistujien yhteiseen alueeseen. Tässä tapauksessa sekä puhuja että kuulija ovat deiktisen keskuksen sisäpuolella. Kuviossa 1 esitän saamen deiktiset demonstratiivit Diesselin (2012, s. 14) mallin mukaisesti.

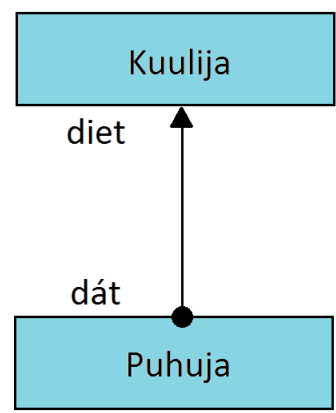

Deiktinen keskus 1

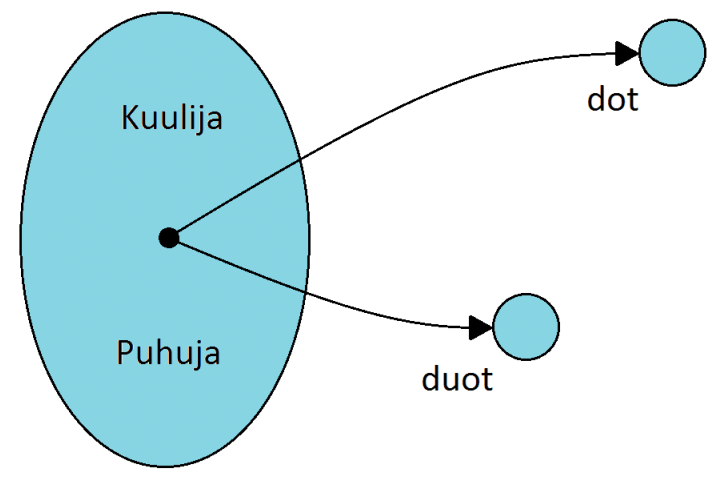

Deiktinen keskus 2

Kuvio 1. Deiktisen keskuksen hahmottuminen Diesselin (2012) mukaan.

Koska distaalisten termien deiktinen keskus hahmottuu puhekumppaneiden yhteiseksi alueeksi, näiden jäsenten tulkitsemiseen tarvitaan enintään kolme eri entiteettiä: deiktinen keskus, joka muodostuu keskustelukumppanien yhteisestä alueesta, ja kaksi muuta entiteettiä, jotka ovat 'kaukana' ja 'kauempana' deiktisestä keskuksesta. Vaikka siis kielissä, joissa on kuulijaa lähelle viittaava demonstratiivi, voi olla neljä (tai useampi) deiktistä jäsentä, niiden spatiaaliseen hahmottamiseen tarvitaan Diesselin (2012) mukaan tavallisesti enintään kolme erillistä viitepistettä. Larjavaara (1985) on esittänyt saman tyyppisen kuvauksen suomen demonstratiivien osalta.
Tämän tutkimuksen aineistossa, radiokeskusteluissa, distaaliset duot ja dot ovat harvinaisia (vain yksi esiintymä kumpaakin), mikä osoittaa, että viiden pronominin systeemi ei ole aktiivisessa käytössä kaikenlaisissa konteksteissa. Keskusteluaineistojen tutkimus onkin paljastanut, että spatiaalisten tekijöiden lisäksi pronominien esiintymiseen ja vaihteluun voi kytkeytyä myös vuorovaikutukseen liittyviä ilmiötä (esim. Etelämäki 2006, Laury 1997, Priiki 2017, Seppänen 1998). Myös Diessel (2006) on kiinnittänyt huomiota demonstratiivien tärkeään rooliin vuorovaikutuksessa. Sen lisäksi että demonstratiivit ilmaisevat referentin spatiaalista 
sijaintia, hän pitää demonstratiivien toisena perustehtävänä koordinoida keskustelijoiden yhteistä huomiota. Diessel toteaa, että vaikka demonstratiivit eivät endoforisessa käytössä viittaa konkreettisiin tarkoitteisiin, ne sisältävät kuitenkin samoja psykososiaalisia mekanismeja, joita puhujat käyttävät tekstinulkoisessa viittaamisessa. Molemmissa tapauksissa demonstratiivit kiinnittävät keskustelijoiden huomion tiettyyn referenttiin. Diesselin mukaan yhteinen huomio (joint attention) ei ole tärkeä ainoastaan keskustelijoiden huomion kohteen koordinoinnin kannalta, vaan sillä on tärkeä tehtävä myös keskustelun jäsentämisessä.
Saamen demonstratiivipronominit voivat esiintyä sekä itsenäisenä lausekkeena että substantiivin määritteenä. Substantiivin määritteenä ne ovat ns. puolikongruenssissa pääsanansa kanssa yleensä siten, että yksikön illatiivissa ja lokatiivissa demonstratiivipronomini on genetiivi-akkusatiivissa ja monikon komitatiivissa puolestaan monikon genetiiviakkusatiivimuodossa. Itämurteissa on myös muita variantteja. (Ks. Nickel \& Sammallahti, 2011, s. 118.) Taulukossa 2 on esimerkkinä dat-pronomini + substantiivi, mutta kaikki demonstratiivipronominit (dát, diet, duot, dot) taipuvat vastaavalla tavalla. Suluissa olevat muodot ovat itämurteisia variantteja.

Taulukko 2. Pohjoissaamen dat várri 'se vuori' -lausekkeen taivutus.

\begin{tabular}{|l|l|l|}
\hline & Yksikkö & Monikko \\
\hline Nominatiivi & dat várri & dat várit \\
\hline Gen.-akk. & dan vári & daid váriid \\
\hline Illatiivi & dan várrái & daidda váriide/(daid váriide) \\
\hline Lokatiivi & dan váris & $\begin{array}{l}\text { dain váriin/(dainna váriin)/ } \\
\text { (daid váriiguin) }\end{array}$ \\
\hline Komitatiivi & dainna váriin & $\begin{array}{l}\text { daid váriiguin/ } \\
\text { daiguin váriiguin }\end{array}$ \\
\hline Essiivi & danin várrin & \\
\hline
\end{tabular}

Kirjallisuuden (Nickel \& Sammallahti, 2011, s. 118-121; Nielsen, 1979, s. 125-128, 359-360; Sammallahti, 1998, s. 117) mukaan pronomineja dát, diet, duot, dot käytetään jostakin, jonka voi nähdä ja johon voi osoittaa, esim. dát lea mu girji 'tämä on minun kirjani'; mii diet lea?'mikä se on (joka sinulla on siellä)?' Pronomini dat puolestaan viittaa johonkin, jota "ajatellaan". Se voi olla jokin, joka on juuri mainittu tai joka on yleisesti tunnettu tai jokin, josta aiotaan sanoa enemmän, esim. Doppe lei busse, mubto movt dal goastá dan busse rádjái? 'Siellä oli bussi, mutta miten sen bussin luo pääsee'; De mii manaimet dan báikái, gos mii dal galgat orrut dan golbma vabku. 'Niin me menimme siihen paikkaan, missä meidän piti olla ne kolme viikkoa'. Myös diet-pronomini voi viitata johonkin, jonka keskustelukumppani on maininnut, esim. Gosbat diet girji lea, maid don ikte namuhit? 'Missä se kirja on, josta eilen mainitsit?' Dat-pronominista mainitaan myös, että sen deiktinen merkitys on vähäinen, ja että sitä käytetään lähinnä anaforisesti. Dat esiintyy - 
suomen se-pronominin tavoin - myös persoonapronominina ja painottavana partikkelina.

Demonstratiivipronominien illatiivi- ja lokatiivimuotoja käytetään usein paikanadverbiaaleina, jolloin ne viittaavat varsin suppeaan alueeseen, esim. Dat lei eske dás 'se oli äsken tässä. Demonstratiiveja voidaan vahvistaa käyttämällä edellä vastaavaa adverbia, esim. Cokka fal die dien biktasa!' pue toki se vaate (joka sinulla on siinä)'. Nämä huudahduksia muistuttavat adverbit (dá, die, duo, do) myös kiinnittävät huomiota, kun osoitetaan jotain tai näytetään tai annetaan jotain, esim. $D a ́$ ! 'kas tässä, ole hyvä (kun annetaan jotain)'; Die dat lea. 'kas siinä (sinulla) se on'. Pronominien kantavartaloista voidaan johtaa myös vastaavat demonstratiiviset proadjektiivit (dákkár(aš), duokkár(aš), dokkár(aš), dakkár(aś) ja diekkár(aś)) ja laaja ryhmä erilaisia adverbejä (Nickel \& Sammallahti, 2011, s. 119, 151, 649; Nielsen, 1979, s. 127).

\section{TUTKIMUSAINEISTO}

Tutkimusaineiston olen koonnut Norjan yleisradioyhtiön saamen yksikön NRK Sápmin nuorille suunnatuista radio-ohjelmista izü ja Dáppe ruovttus ('täällä kotona'). Olen hankkinut radio-ohjelmien kopiot NRK:n nauhoitearkistosta ja litteroinut ne omaa tutkimustani varten. Valitsin tutkimusaineistoksi nuortenohjelmat, koska haluan tutkia nimenomaan nykypuhekieltä ja oletan, että nuorten käyttämä kieli edustaa tätä hyvin. Vaikka tutkimuksen aineisto on Norjasta, missä valtaosa pohjoissaamen puhujista asuu, lienevät sen tulokset pääpiirteissään yleistettävissä koskemaan myös Suomen ja Ruotsin puolella puhuttavaa saamea.

Aineisto koostuu viidestä izü- ja kahdesta Dáppe ruovttus -ohjelmasta, jotka on lähetetty vuosina 2007-2011. Ohjelmat on valittu niin, että edustettuina ovat sekä molemmat sukupuolet että molemmat päämurrealueet (itä- ja länsimurteet). Kaikkiaan aineistossa esiintyy juontajina kahdeksan nuorta aikuista, joista viisi on naisia ja kolme miehiä. Heistä viisi on kotoisin Norjan Kaarasjoen ja kolme Koutokeinon alueelta. He juontavat ohjelmia tavallisesti pareittain. izüssa juontajat käsittelevät nuoria kiinnostavia ajankohtaisia aiheita, haastattelevat ihmisiä ja soittavat musiikkia. Sisällöltään izü on asiapitoisempi kuin Dáppe ruovttus, joka on usein hyvin humoristinen. Siinä kaksi nuorta miestä tekevät ohjelmaa opiskelija-asunnossaan Tromssassa (tästä myös ohjelman nimi 'täällä kotona'). Molemmat ohjelmat kestävät tavallisesti tunnin. Keskustelumateriaalia on kertynyt yhteensä noin kolme tuntia.

Radio-ohjelmat sopivat mainiosti tutkimusaineistoksi, sillä oletukseni mukaan niissä demonstratiiveja ei juurikaan käytetä eksoforisesti, vaan endoforisesti viitaamassa diskurssin sisäisiin referentteihin. Radioaineiston lisäksi olen teettänyt pienelle opiskelijaryhmälle testin erään radiokeskustelukatkelman pohjalta. Testissä opiskelijoiden tuli täyttää sopivimmiksi katsomansa demonstratiivipronominit pois jätettyjen pronominien tilalle. Testin tarkoituksena oli saada lisätietoa pronominien käytöstä ja vaihtelusta.

Olen aluksi poiminut aineistosta kaikki substantiivilausekkeet, joita määrittää jokin demonstratiivipronomini. Tällaisia lausekkeita kertyi yhteensä 497. Tavallisin adnominaalinen pronomini on dat'se'. Se esiintyy lähes 80 $\%$ :ssa tapauksista. Dát + NP -esiintymiä on $12 \%$ ja diet + NP -tapauksia noin $9 \%$. Duot + NP ja dot + NP esiintyvät kumpikin yhden kerran (taulukko 3). Länsimurteisten idiolektien kohdalla ei ollut aina aivan selvää sanooko puhuja dat / tah(t)/ 'se' vai dát / taah(t)/ 'tämä. Näitä ongelmatapauksia ratkoimme parhaan kykymme mukaan yhdessä opiskelija Inger Máret Ánne Eiran kanssa, jonka äidinkieli kuuluu länsimurteisiin. Itämurteissa dát ääntyy /tääh(t)/, joten niissä ero on helpompi 
kuulla. Voi olla, että länsimurteissa pronominien dát ja dat ero on katoamassa, mutta asian varmistaminen vaatii tarkempaa tutkimista.

Seuraavaksi olen rajannut kaikista pronominitarkenteisista lausekkeista tarkastelun ulkopuolelle eksoforiset viittaukset. Eksoforisessa käytössä ovat molemmat duot- ja dot-tapaukset sekä kolmannes dát + NP -esiintymistä. Ero ilmauksen deiktisen ja anaforisen käytön välillä ei välttämättä ole aina selvärajainen. Eksoforiseksi olen tulkinnut esimerkiksi tapaukset, joissa juontajat viittaavat meneillään olevaan lähetykseen tai ohjelmaan. Esimerkiksi lauseessa dál boabtá munno vuosttaš lávlla dán prográmmas 'nyt tulee ensimmäinen laulumme tässä ohjelmassa' tulkitsen, että dán prográmmas viittaa deiktisesti meneillään olevaan tilanteeseen. Se on rinnastettavissa sellaisiin paikan ja ajan ilmauksiin kuten tässä huoneessa tai tänä päivänä. Periaatteessa meneillään oleva ohjelma tai lähetys on voitu mainita aiemmin, ja usein onkin, mutta ensisijaisesti tarkoite on kuitenkin tunnistettavissa puhetilanteen pohjalta.

Tilanneviitteisiksi eli eksoforisiksi olen tulkinnut myös sellaiset tapaukset, joissa juontaja viittaa dát + NP -lausekkeella nettisivuun, joka selkeästi tuntuu olevan avoinna hänen edessään (dálgo mun dás čobkkán ja geabčadan dán siiddu' nyt kun minä tässä istun ja katselen tätä sivua'). Englannissa dát-pronominia vastaava this on samanlaisessa käytössä (this article, in this book), ja Himmelmann (1996, s. 221) pitää niitä tilanteisena käyttönä, vaikkakin tällaisia viittauksia kielelliseen yksikköön tai tekoon on pidetty joskus myös diskurssideiktisen käytön alatyyppinä.

Endoforisina esiintyvät pronominit dat, dát ja diet. Keskityn tarkastelemaan pääasiassa pronomineja dát ja diet (tapaukset merkitty harmaalla taulukossa 3), koska olen tutkinut dat-pronominin käyttökonteksteja saman aineiston pohjalta toisaalla (Guttorm, 2015). Kuitenkin, erityisesti pronominien eroja pohtiessani, käsittelen jonkin verran myös dat-pronominin käyttöä.

Taulukko 3. Tutkimusaineiston endoforiset ja eksoforiset pronominitarkenteiset substantiivilausekkeet.

\begin{tabular}{|l|l|l|l|l|l|l|}
\hline & dat + NP & diet + NP & dát + NP & duot + NP & dot + NP & Yht. \\
\hline & & & & & & \\
\hline Endoforiset & 387 & 47 & 42 & 0 & 0 & 476 \\
\hline Eksoforiset & 0 & 0 & 19 & 1 & 1 & 21 \\
\hline Yhteensä & 387 & $\mathbf{4 7}$ & $\mathbf{6 1}$ & $\mathbf{1}$ & $\mathbf{1}$ & $\mathbf{4 9 7}$ \\
\hline
\end{tabular}

Endoforiset diet + NP ja dát + NP -lausekkeet olen analysoinut edelleen pragmaattisen käytön mukaan anaforiseen, kataforiseen ja rekognitionaaliseen käyttöön. Suurin osa diet + NP ja dát + NP -lausekkeista on anaforisia (taulukko 4). Dát + NP -lausekkeita käytetään viittamaan myös kataforisesti, mutta diet + NP -lausekkeita ei lainkaan.
Diet + NP -lausekkeita käytetään vastaavasti enemmän rekognitionaalisesti kuin dát + NP -lausekkeita. Lausekkeiden muut käytöt ovat ensimainintoja, joiden tarkoitteet voivat olla tunnistettavissa jonkin toisen aiemmin mainitun tarkoitteen, kontekstin tai muutoin yleisen pragmaattisen tiedon perustella. 
Taulukko 4. Diet- ja dát-tarkenteisten substantiivilausekkeiden käyttö.

\begin{tabular}{|l|l|l|l|l|l|}
\hline & Anaforiset & Kataforiset & $\begin{array}{l}\text { Rekognitio- } \\
\text { naaliset }\end{array}$ & Muut & \\
\hline & & & & & \\
\hline diet + NP & 38 & 0 & 7 & 2 & 47 \\
\hline dát + NP & 27 & 8 & 2 & 5 & 42 \\
\hline Yhteensä & $\mathbf{6 5}$ & $\mathbf{8}$ & $\mathbf{9}$ & $\mathbf{7}$ & $\mathbf{8 9}$ \\
\hline
\end{tabular}

\section{POHJOISSAAMEN DEMONSTRATIIVIEN KÄYTTÖ}

Tarkastelen seuraavaksi saamen adnominaalisten demonstratiivipronominien endoforista käyttöä. Nuorten radiokeskusteluissa endoforisina pronomineina esiintyvät dat, diet ja dát. Myös duot-pronominin endoforisesta käytöstä löytyy esimerkkejä (ks. Guttorm, 2009; Sammallahti, 2005, s. 229), vaikka tässä aineistossa sitä ei esiinnykään. Analyysiosan olen ryhmitellyt siten, että tarkastelen aluksi dat- ja diet-pronomineilla viittaamista, joka on pääasiassa anaforista. Tarkastelun painopiste on diet-pronominin käytössä. Seuraavaksi esittelen dát-pronominin käyttöä, jolla viitataan sekä eteen- että taaksepäin. En käsittele erikseen diskurssideiktistä käyttöä, vaan sisällytän sen anaforiseen käyttöön. Ennen pohdintaosiota tarkastelen vielä pronominien diet ja dát rekognitionaalista käyttöä.

\subsection{Anaforiset dat 'se' ja diet 'se (siinä)'}

Anaforisessa käytössä selkeästi tavallisin pronomini on dat. Se muodostaa lähes 80 \% kaikista aiemmin mainittuihin referentteihin viittaavista pronominitarkenteisista lausekkeista. Jo Nielsen (1979, s. 125) mainitsee kieliopissaan, että dat-pronominin deiktinen merkitys on vähäinen, ja myöhemmin Sammallahti $(1998$, s. 117) on todennut, että dat- pronominin käyttö on rajoittunut anaforisiin tapauksiin. Adnominaalista dat-pronominia käytetään viittaamaan juuri edellä mainittuihin keskeisiin referentteihin. Referentin maininnasta voi myös olla kulunut jonkin aikaa, ja dat + NP -lausekkeen avulla se nostetaan uudelleen keskusteluun (ks. myöhemmin esimerkit 4-5). Dat + NP voi viitata myös diskurssideiktisesti yksittäistä tarkoitetta laajempaan tekstin osaan.

Adnominaalista dat-pronominia käytetään myös viittaamassa eteenpäin, joskin aineistossa on vain muutamia tällaisia tapauksia. Kataforisessa viittauksessa dat + NP:n tarkoite voi tarkentua jäljessä seuraavan märirtteen perusteella, esimerkiksi leagot nu abte dán jagi soitet vehá, in mun juo gillán dadjat gal dan sáni mubto mun dajan goitge, jierpmábut goalmmát jagi studeant- dege oahppit' onko niin, että tänä vuonna on vähän, en aikonut sanoa sitä sanaa, mutta sanon kuitenkin, järkevämpiä kolmannen vuoden opiskelijoita'. Tarkoite voi selvitä myös jäljessä seuraavan kun-lauseen pohjalta kuten seuraavassa erään ohjelman ensimmäisen jutun aihe: juo ja dál mii beassat gullat dan vuosttaš ášš go lea nu abte mun humadin Johan Sara junioriin - 'joo ja nyt pääsemme kuulemaan sen ensimmäisen jutun, kun on niin, että minä juttelin Johan Sara juniorin kanssa - - .

Myös diet + NP -lausekkeista suurin osa viittaa aiemmin mainittuihin tarkoitteisiin. 
Mielenkiintoista on, että ainakin tämän tutkimuksen aineistossa, radiokeskusteluissa, edellä mainittu tarkoittaa usein edellä kuultua. Tällaisia on noin puolet anaforisista diet + NP -lausekkeista. Edellä kuultuun musiikkiin viitataan aina diet-pronominilla kuten esimerkissä (1) musiikkikappaleen lo- puttua. Edellä kuultu voi musiikin lisäksi olla myös haastateltu henkilö. Esimerkissä (2) diet bárdni viittaa aiemmin nauhoitetussa osiossa haastateltuun poikaan. Juontajan repliikki on heti nauhoitetun osion jälkeen. Kielitajuni perusteella suomessa vastaavassa tilanteessa tuo-pronomini olisi luontevin.

(1) [izü 13.5.2008]

$\mathrm{E}$ : dies lei nu finna loahppa dien lávlagis

diet.LOK olla.PRET.3sg niin hieno loppu diet.GA laulu.LOK

'siinä/tuossa oli niin hieno loppu siinä/tuossa [äsken kuullussa] laulussa'

(2) [izü 11.9.2007]

$\mathrm{E}$ : gulletgon diet bárdni logai dat lea buorre

kuulla.PRET.2SG.KYs diet poika sanoa.PRET.3sg se olla.3sg hyvä

go olbmot buorrestit olbmuid

kun ihminen.PL halata.3PL ihminen.PL.GA

'kuulitko, se/tuo [äsken kuultu] poika sanoi, että on hyvä, kun ihmiset halaavat toisiaan'

Olen aiemmin esittänyt esimerkin (2) kaltaista tapausta tilanneviitteiseksi, jolloin referentti olisi tilanteessa läsnä kuulohavainnon kautta (ks. Guttorm, 2015, s. 20). Tällaisen tapaukset rinnastuisivat tilanteeseen, jossa keskustelukumppanit esimerkiksi kuulevat kovan pamahduksen tai näkevät valonleimahduksen, ja yksi heistä kysyy mii diet lei?'mikä se oli'. Larjavaara (1990, s. 127-130) puhuu auditiivisesta havaintopiiristä, jolloin viittaaminen esimerkiksi musiikkiin ja puhekumppanien tuottamiin ääniin on eksoforista. Hänen mukaansa kuultuun ääneen voidaan suomessa viitata kaikilla kolmella demonstratiivipronominilla: tämä/tuo/se oli harppu.

Etelämäki (2006, s. 198-200) on luonnehtinut suomen tuo-pronominia referentiaalisesti avoimeksi. Referentiaalisesti avoin viittaus osoittaa, että tarkoite on keskustelijoiden tunnistamisen ja tulkinnan kohteena. Se ei siis ilmaise tarkoitetta riittävän tunnetuksi meneillään olevassa toiminnassa. Pronomini tuo ilmaisee, että tarkoite on tunnistettavissa jossain osallistujien jo jakamassa tulkintakehyksessä, jolloin se on funktioltaan osoittava. Etelämäen mukaan suomen pronomini se puolestaan implikoi riittävää tunnettuutta, ja on tunnusmerkitön viittaava pronomini. Diet muistuttaa suomen tuo-pronominia siinä mielessä, että esimerkeissä 1 ja 2 diet + NP osoittaa tarkoitteen tunnistamisen ja huomion kohteeksi. Tunnistaminen puolestaan pohjautuu yhteiseen kuulohavaintoon, joka toimii siis tarkoitteiden tulkintakehyksenä. Toisaalta kuten myöhemmissä esimerkeissä tulee esille, diet + NP voi implikoida myös, että tarkoite on keskustelijoille riittävän tuttu. Näin ollen saamen diet-pronominissa on samoja piirteitä kuin suomen sekä tuo- että se-pronominissa.

Mielenkiintoista on, että võrun kielestä voi löytää jonkinlaista samankaltaisuutta demonstratiivien käytössä saamen kanssa, sillä Pajusalu (2015, s. 182) on esittänyt esimer- 
kin, jossa vốrun mediaalinen taa-pronomini viittaa kuultuun ääneen. Võrun demonstratiivijärjestelmä on muuttumassa, mutta vanhastaan taa on luultavasti viitannut kuulijaa lähellä oleviin tarkoitteisiin kuten saamen diet.

Kielioppien (esim. Nickel \& Sammallahti, 2011, s. 118; Nielsen, 1979, s. 125) mukaan diet voi viitata johonkin sellaiseen, jonka nimenomaan keskustelukumppani on maininnut. Joskus merkitys voi olla myös 'se jota "ajattelet" tai josta juuri äskettäin puhuimme'. Tällaisesta käytöstä on kysymys seuraavassa esimerkissä (3). Katkelmassa juontajakaksikko oli ollut Kaarasjoen keskustassa toteutta- massa amerikkalaista teemapäivää Free Hug Day. Heidän kokemuksensa mukaan miehet olivat innokkaampia halaamaan kuin naiset, ja Åse aikoikin kertoa kuuntelijoille eräästä naisesta (okta ábkku'yks muori'), joka oli kertonut, miksi kaikki naiset eivät halunneet halata heitä, mutta sitä ennen he päättivät soittaa musiikkia. Musiikin jälkeen Ellen viittaa Åsen mainitsemaan naiseen diet-lausekkeella (dien ábku birra 'siitä muorista'). Huomaa, että samassa yhteydessä Ellen viittaa jälleen myös edellä kuultuun artistiin diet-pronominilla: diet lei Chuck Willis'se oli Chuck Willis'.

(3) [izü 11.9.2007]

$\mathrm{E}$ : juomunin muitán muitalit ovdal musibka diet joo 1SG NEG.1SG muistaa.PART.PRF kertoa.INF ennen musiikki.gA diet lei ChuckWillis gii dan lávllui, vai(Jock) vai mot olla.PRET.3sG Chuck Willis jokadat.GA laulaa.PRET.3sg vai (Jock) vai miten datgalgá lobkat, juo Asedonmuitalitge dien ábku se pitää.3sg sanoa.INF joo Åse 2sG kertoa.PRET.2SG.KIN diet.GA muori.GA birra ympäri.POSTP 'joo, minä en muistanut kertoa ennen musiikkia, [että] se oli Chuck Willis, joka sen lauloi, tai Jock, vai miten sitä pitää sanoa, joo Åse, sinä kerroitkin [äsken] siitä muorista [joka ei halunnut halata]'

Diet + NP on siis ymmärrettävissä niin, että Ellen viittaa sillä naiseen, jonka Åse on ennen musiikkikappaletta maininnut. Lausekkeen voi tulkita myös niin, että se viittaa toiseen yhteyteen, nimittäin haastattelutilanteeseen Kaarasjoen keskustassa ja siellä olleeseen naiseen. Näin tarkoite on molemmille tuttu yhteisen kokemuksen perusteella. Tässä suhteessa diet muistuttaa jälleen Etelämäen (2006, s. 199) kuvausta suomen tuo-pronominista, joka ilmaisee, että tarkoite on tunnistettavissa jossain keskustelijoiden jo jakamassa tulkintakehyksessä. Kuitenkaan vastaavassa suomenkielisessä tilanteessa kielitajuni mukaan tuo ei olisi luonteva vaan nimenomaan $s e$. Etelämäen mukaan suomen tuo onkin funktioltaan osoittava pronomini ja se viittaava. Jos dietpronominin paikalla olisi dat, merkityksestä jäisi puuttumaan viittaus toiseen yhteyteen, yhteiseen kokemukseen, ja ilmaus olisi ymmärrettävissä ainoastaan anaforiseksi viittaukseksi Åsen ennen musiikkia mainitsemaan muoriin.

Diet + NP voi siis viitata myös sellaiseen aiemmin mainittuun tarkoitteeseen, joka esiintyy toisessa yhteydessä. Esimerkissä (4) sekä itsenäisillä että adnominaalisilla dietlausekkeilla viitataan nettisivulle, tällä kertaa 
iltapäivälehti Verdens Gangin (VG) nettisivulla olevaan juttuun ja siinä esiintyviin referentteihin. Ritva esittelee uuden aiheen kysymällä Olelta, arvaako tämä mitä hän on lukenut netistä viime aikoina, nimittäin että nuoret lähtevät etelään juhlimaan ja rellestämään. Sitten Ritva kysyy Olelta, onko tämä kuullut "niistä asioista" (dieid ášsiid birra) käyttäen diet-pronominia viittaamassa nimenomaan nettisivulla mainittuihin asioihin. Myös Ole käyttää diet-pronominia, kun hän viittaa Ritvan mainitsemaan juttuun VG:n nettisivulla. Olen alleviivannut esimerkistä diet-pronominit, joiden voisi tulkita viittaavan myös keskustelukumppanin edellä mai- nitsemaan asiaan tai tarkoitteeseen. Keskustelusta käy ilmi, että nettisivulla on ollut myös filmi, jonka he kumpikin ovat katsoneet (dien filmma-dien).

Diet-pronominin peräkkäisten esiintymien taustalla voi olla myös ns. priming-ilmiö, joka tarkoittaa, että puhujat ovat taipuvaisia käyttämään sellaisia sanoja, muotoja ja rakenteita, jotka ovat esiintyneet keskustelussa jo aiemmin (Bock \& Griffin 2000). Esimerkiksi Priiki (2014, s. 103) on havainnut tutkiessaan suomen subjektina toimivia persoona- ja demonstratiivipronomineja, että pronominien vaihtelussa tärkein selittäjä on se mitä pronominia samasta henkilöstä on edellä käytetty.

(4) [izü 23.7.2009]

$\mathrm{R}$ : - - hás it árvit maid mun lean dál manimuśáiggiid lobkan doppe neabtas 'et arvaa mitä minä olen lukenut nyt viime aikoina tuolta netistä'

O: ná 'no?'

R: VGa neahttasiidduin doppe lea dál leamaš dakkár ášsi abte nuorat vulget dobko lieggariikii ja hirbmat sakka doppe festejit ja jubket ja, leatgon gullan dieid ášsiid birra olla.2sG.KYs kuulla.PART.PRFdiet.PL.GA asia.PL.GA ympäri.POSTP

'VG:n nettisivuilla, siellä on ollut nyt sellainen juttu, että nuoret lähtevät tuonne etelänmaille ja kauheasti siellä juhlivat ja juovat ja, oletko kuullut niistä jutuista?'

$\mathrm{O}$ : dien mun lean oaidnán dien dien mun gehččen diet.GA $1 \mathrm{sg}$ olla.1sG nähdä.PART.PRF diet.GA diet.GA $1 \mathrm{sg}$ katsoa.PRET.1sG maid dien filmma ja diet orui issoras measta mu mielas myös diet.GA filmi.GA ja diet tuntua.PRET.3sg kamala melkein 1sG.GA mieli.LOK 'sen minä olen nähnyt sen sen minä katsoin myös sen filmin, ja se tuntui minusta melkein kamalalta' $\mathrm{R}$ : juo mun maid gehčcen dien ja das oidnui mot dat joo 1sG myös katsoa.PRET.1sG diet.GA ja se.LOK näkyä. PRET.3SG miten se.PL nuorat doppefestejedje ja,ná, dat orui oallenuori.PL siellä juhlia.PRET.3PL ja niinse tuntua.PRET.3sG melko 'joo, minä myös katsoin sen, ja siinä näkyi, miten ne nuoret siellä juhlivat ja, niin, se tuntui melko-'

Teetin syksyllä 2017 yllä olevan katkelman pohjalta testin muutamille Saamelaisen korkeakoulun opiskelijoille. Testissä opiskelijoi- den tuli täyttää sopivimmiksi katsomansa demonstratiivipronominit pois jätettyjen tilalle. Testissä oli mukana kahdeksan äidinkie- 
listä saamen kielen perusopintoja suorittavaa opiskelijaa Norjasta, Suomesta ja Ruotsista. Tämän testin perusteella diet-pronominien sijalla voisi olla myös dat. Jakauma dat- ja diet-pronominien välillä oli noin puolet ja puolet. Ainoa tapaus, jossa lähes kaikki opiskelijat ehdottivat vain dat-pronominia, on Olen viimeisessä repliikissä dien fllmma 'sen filmin'. Tässä tapauksessa referentti mainitaan ensimmäisen kerran, muissa tapauksissa referentti on mainittu aiemmin.

Opiskelijoille teettämäni testi antaa viitteitä siitä, että dat- ja diet-pronominit ovat merkitykseltään läheisiä anaforisessa käytössä. Edellä mainitun tarkoitteen ei tarvitse olla keskustelukumppanin mainitsema tai esiintynyt aiemmin toisessa yhteydessä, jotta siihen voidaan viitata diet-pronominilla. Tästä esimerkkinä seuraava katkelma. Keskustelun aiheena on piirroshahmo Johnny Bravo, johon juontajat ovat aikaisemmin viitanneet sekä itsenäisillä että adnominaalisilla dat-, diet- ja dát-lausekkeilla ja persoonapronominilla son 'hän'. Keskustelun lopussa Ole viittaa Johnny Bravoon ensin dat + NP:1lä ja tämän jälkeen diet + NP:llä. Näissä tapauksissa en näe mitään merkittävää eroa pronominien merkitysten välillä, vaan molemmissa viittauksissa sekä dat että diet ovat mahdollisia.

\section{(5) [izü 23.7.2009]}

O: - - josáiggut oahppat eambbo dan Johnny Johnny Bravo jos haluta.2sG oppia.INF enemmän dat.GA Johnny Johnny Bravo birra de manat duššeGungelis jadien olbmá dušse ympäri.POSTP niin mennä.2sG vain Google.LOK ja diet.GA kaveri.GA vain čálát Johnny Bravo pick up lines - kirjoittaa.2sG Johnny Bravo pick up lines ' - - jos haluat oppia enemmän siitä Johnny Bravosta, niin menet vain Googleen ja kirjoitat sen kaverin [nimen], ”Johnny Bravo pick up lines" - -'

Diet- ja dat-pronominien samankaltaisuus tulee esille myös seuraavassa Olen repliikissä. Radio-ohjelman aikoihin Islannissa oli purkautunut tulivuori, jonka savu haittasi lentoliikennettä Euroopassa. Iuontaiakaksikko on vuhunut aiheesta aiemmissa lähetyksissä, mutta Ole haluaisi kertoa vielä yhden mieleensä tulleen asian. Hän etsii sopivaa sanaa, jolla viitata tulivuoreen, ja tässä yhteydessä hän käyttää ensin pronominia dat ja sitten pronominia diet ennen kuin lovussa lövtää sanan vulkána 'tulivuori'.

(6) [izü 22.4.2010]

O: --munlean bui olu olu olu olu jurddašan dál

1sG olla.1sG hyvin paljon paljon paljon paljon ajatella.PART.PRF nyt

dien, dan, dolla-, ná, vulkána diet.GA dat.GA tuli- niin vulkaani.GA

'minä olen hyvin hyvin paljon ajatellut sitä, sitä, tuli-, niin, vulkaania' 
Odotuksenmukaisesti aineistossa ei tule esille tapauksia, joissa diet olisi kataforinen eli viittaisi keskustelussa eteenpäin. Vaikka dat- ja diet-pronominit ovat samankaltaisia anaforisessa käytössä, niin diet ei kävisi esimerkiksi tämän luvun alussa esitettyihin esimerkkeihin, joissa dat esiintyy kataforisessa käytössä. Niissä diet-pronominin käyttö antaisi vaikutelman, että viitataan johonkin toiseen yhteyteen. Tämä vahvistaa käsitystä siitä, että diet-pronomini on endoforisessa käytössä ennen kaikkea anaforinen pronomini. Sen sijaan dát voi olla myös kataforinen, jonka käytöstä seuraavaksi.

\subsection{Anaforinen ja kataforinen dát 'tämä'}

Adnominaalisella dát-pronominilla voidaan viitata keskustelussa sekä eteen- että taaksepäin. Kaikki aiemmin mainitut referentit, joihin viitataan dát-tarkenteisella lausekkeel- la, ovat keskustelussa keskeisiä tarkoitteita tai teemoja. Pronominin käyttö nostaa tarkoitteen fokukseen. Myös muista kielistä on havaintoja, että lähelle viittaavat pronominit osoittavat tarkoitteen voimakkaan huomion kohteeksi (Etelämäki, 2006, s. 173-175; Kirsner, 1990; Laury, 1997, s. 62; Strauss, 2002).

Seuraavassa esimerkissä Dáppe ruovttus -ohjelman juontajat tekevät pilaa hirvenpyynnistä. Uuden ehdotuksen mukaan hirvenmetsästäjät saisivat käyttää apuna ainoastaan hevosia. Keksityssä jutussa toimittaja vierailee erään hevosenomistajan luona, joka on jo panostanut hevosten vuokraamiseen. Kun reportteri viittaa ehdotukseen hevosten käyttämisestä apuna hirvenmetsästyksessä, hän käyttää dát-tarkenteista lauseketta dát evttohus 'tämä ehdotus'. Dát-pronominin käyttö nostaa jo aiemmin mainitun keskustelun teeman fokukseen.

\section{(7) [Dáppe ruovttus 5.11.2010]}

$\mathrm{J}$ : - - mubtogoitge dat leat olu ealgabivdit geat leat

mutta kuitenkin se.PL olla.3PL paljon hirvenpyytäjä.PL joka.PL olla.3PL

subttan dán evttobusa ektui mubtodonleat okta
suuttua.PART.PRF dát.GA ehdotus.GA jnk suhteen mutta 2 sG olla.2sG yksi dain gii leat maiddái ealgabivdi mubtodon leat oalle se.PL.LOK joka olla.2sG myöskin hirvenpyytäjä mutta 2sG olla.2sG melko ilus dán evttobusa badjel ilo.LoK dát.GA ehdotus.GA yli.POsTP

' - - mutta kuitenkin on monia hirvenpyytäjiä, jotka ovat suuttuneet tästä ehdotuksesta, mutta sinä olet yksi niistä, joka olet myös hirvenmetsästäjä, mutta olet melko iloinen tästä ehdotuksesta'

Esimerkissä (8) huomion kohteena olevaan tarkoitteeseen - jo esimerkissä (5) esiintyneeseen Johnny Bravoon - viitataan dát-tarkenteisten lausekkeiden lisäksi myös monilla muilla ilmaisuilla. Ohjelman aiheena on naisten iskeminen, ja tässä yhteydessä Ole nostaa esille Johnny Bravon, joka on hänen esikuvansa iskemisen saralla. Johnny Bravo on amerikkalaisen piirrossarjan päähenkilö, joka on tunnettu muun muassa machomaisista iskulauseistaan. Aluksi Ole esittelee tarkoitteen sanomalla, että hänellä on ”yks 
esikuva" iskemisessä. Sen jälkeen hän viittaa Johnny Bravoon sekä itsenäisillä että dát-tarkenteisilla lausekkeilla. Juontajakollega Ritva ei ole aluksi varma kenestä on kyse, ja hän kysyykin leago diet almmái geas leat stuorra fiskes vuovttat ('tarkoitatko sitä tyyppiä, jolla on iso keltainen tukka') käyttäen diet + NP:tä viitatessaan Olen mainitsemaan tarkoitteeseen. Kun Ritva saa tietää kenestä on kyse, Ole jatkaa keskustelua esittäen esimerkkejä Johnny Bravon iskurepliikeistä. Hän viittaa esikuvaansa persoonapronomineilla son 'hän' ja dat 'se', sekä useita kertoja ilmaisuilla dát olmmái 'tämä kaveri' ja dát 'tämä'.

Runsas dát-pronominin käyttö osoittaa tarkoitteen erityisen huomion keskipisteeksi. Toisinaan se antaa jopa vaikutelman, että referentti olisi Olen edessä ja viittaus näin ollen eksoforinen. Tilanneviitteinen käyttö voi hyvinkin olla mahdollista, sillä jossain vaiheessa Ole mainitsee, että hänellä on edessään paperi, josta hän yrittää löytää esimerkkejä Bravon nasevista iskurepliikeistä. Keskustelu, jossa juontajat juttelevat Johnny Bravosta, on pitkä esitettäväksi tässä kokonaisuudessaan, joten valitsin kohdan, jossa esiintyy monenlaisia ilmauksia viittamassa Johnny Bravoon. Nämä ilmaukset olen merkinnyt lihavoinnilla. Keskustelunpätkä on Olen vastausaloitus Ritvan kysymykseen, millaisia kosiskelukonsteja Johnny Bravolla nyt sitten on, kun he ovat ensin päässeet yhteisymmärrykseen kenestä on kyse.

(8) [izü 23.7.2009]

\section{O: ná das lávejit dat maidson dadjá dat leat vehá}

niin dat.LOK olla tapana.3sg se.PL mitä 3 sg sanoa.3sg se.PL olla.3sg vähän suobttasat,go, ná,mot mun galggan dadjat, dátolmmáil- in mun

hauska.PL kun no miten 1sG pitää.1SG sanoa.INF dát kaveri o- NEG.1sG 1sG diece gos dátfuobmá dáid sániid mubtodatlea

tietää.KNG mistä dát huomata.3sg dát.PL.GA sana.PL.GA mutta dat olla.3sG

oalle oalle čeahppi goit

aika aika etevä kuitenkin

'no sillä on tapana [olla], ne mitä hän sanoo, ne on vähän hauskoja, kun, no, miten sanoisin, tämä kaveri on-, en minä tiedä, mistä tämä keksii nämä repliikit, mutta se on kyllä aika etevä

Koko keskustelussa (jota en tilanpuutteen vuoksi voi esittää tässä kokonaisuudessaan) saamen dát-pronomin käyttö viittaamassa Johnny Bravoon vastaa Priikin (2017, s. 61) tuloksia, jonka mukaan suomessa tää-pronominia käytetään, kun puhuja olettaa tietävänsä referentistä enemmän kuin vastaanottaja, referentti on keskustelun aiheen kannalta keskeinen ja sitä määritellään, kunnes keskustelijoilla on riittävän yhteinen käsitys tarkoitteesta.
Etelämäki (2006, s. 59) on todennut suomen tämä-pronominin ilmaisevan aina, että tarkoitteen tunnistaminen (mitä tarkoitteesta tiedetään) on meneillään olevassa toiminnassa keskeistä. Tämä koskee sekä ensi- että uudelleenmainintoja. Etelämäen mukaan suomessa pronominia tämä ei kuitenkaan yleensä käytetä viittaamaan samaan tarkoitteeseen monta kertaa peräkkäin, koska sitä käytettäessä tilanteessa tapahtuu aina muutos. Muutoksella Etelämäki tarkoittaa, 
että tarkoitteen ominaisuudet ja meneillään oleva toiminta saavat tavalla tai toisella uuden tulkinnan.

Dát-tarkenteisilla lausekkeilla viitataan myös eteenpäin, tyypillisesti seuraavaksi kuultavaan musiikkikappaleeseen. Esimerkiksi dáid musibkaidge 'nämä kappaleet' -lausekkeella juontaja viittaa kappaleisiin, jotka he aikovat soittaa ohjelmassaan (moai áigo juobe dáid musibkaidge čuojahit odne 'aiomme ainakin nämä kappaleet soittaa tänään'). Viittauksen jälkeen kappaleista kuullaan lyhyt kooste.

Dát + NP:llä voi viitata eteenpäin myös ohjelman seuraavaan aiheeseen. Tällöin dát + NP:n tarkoite selviää esimerkiksi jäljempänä tulevan että-lauseen perusteella: - - mun smibtten moai sábtte vehá dego dáikit dán ášsi birra dan abte dán vabkuhan gávdne Ameribkás dakkár, njulgestaga ovtta tunealla mii manná Meksikos Ameribkkái - - 'minä ajattelin, että mehän voimme vähän jutustella tästä asiasta, siitä että tällä viikollahan löydettiin Amerikasta sellainen, suorastaan tunneli, joka menee Meksikosta Amerikkaan'.

\subsection{Rekognitionaalinen käyttö}

Adnominaalisilla dat-, diet- ja dát-pronomineilla voidaan viitata myös sellaisiin tarkoit- teisiin, joita ei ole mainittu keskustelussa aiemmin. Näissä tapauksissa voi olla kyse pronominin rekognitionaalisesta tai assosiatiivisanaforisesta käytöstä. Himmelmannin (1996) mukaan rekognitionaalisessa käytössä puhuja olettaa kuulijan pystyvän tunnistamaan tarkoitteen heidän yhteisen spesifisen tietonsa tai kokemuksensa perusteella. Assosiatiivisessa anaforassa tarkoite on pääteltävissä kontekstin perusteella, vaikka sitä ei olekaan ilmaistu edeltävässä puheessa (VISK, \$1438).

Seuraava esimerkki havainnollistaa adnominaalisen diet-pronominin ja siitä johdetun adjektiivimuodon diekkár käyttöä viittaamassa tarkoitteeseen, tai pikemminkin sen ominaisuuksiin, jota ei ole aiemmin mainittu. Ellen on kertonut aiemmin, että hän on sinä päivänä tilannut sellaisia rannekoruja (dakkár giebtabáttiid), joissa on jokin teksti. Sitten hän kysyy Åselta, muistaako tämä niitä rannekoruja (diet giehtabáttit), sellaisia silikonirannekkeita, joita tapasi olla joitakin vuosia sitten. Diet giehtabáttit on ensimmäinen viittaus näihin tietynlaisiin rannekkeisiin. Ellen käyttää siinä diet-tarkenteista substantiivia ja diet-pronominista johdettua adjektiivia diekkár vedoten Åsen muistiin ja kokemukseen kyseisistä rannekkeista. Myös suomessa tavataan semmoneadjektiivin käyttöä, jonka voi tulkita rekognitionaaliseksi (Juvonen, 2000, s. 37).

(9) [izü 13.5.2008]

$\mathrm{O}$ : muittátgon dalle moadde jagi áigi ledje muistaa.2SG.KYs silloin muutama vuosi.GA aika olla.PRET.3SG diet giehtabáttit, diekkár nu gohčoduvvon silikongiehtabáttit diet.PL ranneke.PL sellainen.PL niin kutsuttu silikoniranneke.PL 'muistatko, silloin muutama vuosi sitten oli niitä rannekkeita, sellaisia niin sanottuja silikonirannekkeita' 
Puhuteltu muistaa rannekkeet, ja tämän jälkeen molemmat viittaavat kyseisenlaisiin rannekkeisiin diet-pronominilla ja siitä johdetuilla adverbi- ja adjektiivimuodoilla. Myöhemmät viittaukset ovat anaforisia, mutta diet-pronominin ja sen johdosten käyttö antaa vaikutelman, että juontajat viittaavat aikaisempaan yhteiseen kokemukseen, aikaan kun silikonirannekkeet olivat edellisen kerran käytössä.

Aiemmin esimerkissä (4), jossa esittelin anaforisella diet-pronominilla viittaamista toiseen yhteyteen, tuli esille myös aiemmin mainitsematon tarkoite, VG-iltapäivälehden nettisivulla ollut filmi. Filmiä, johon Ole viittaa ensimmäisen kerran lausekkeella dien filmma 'sitä filmiä, ei ole siis aiemmin mainittu, mutta keskustelusta voi päätellä, että he molemmat ovat olleet VG:n nettisivulla ja nähneet filmin. Näin sen voi olettaa tunnetuksi keskustelijoiden yhteisen kokemuksen kautta, jolloin diet-pronominia käytetään rekognitionaalisesti.

Adnominaalista dát-pronominia käytetään endoforisissa ensimaininnoissa huomattavan vähän, sillä materiaalissa esiintyy ainoastaan kaksi tapausta, joissa dát + NP -lausekkeella viitataan tarkoitteisiin, joiden voi olettaa olevan keskustelijoille tuttuja yhteisen kokemuksen perusteella. Ensimmäisessä esimerkissä dát + NP:llä viitataan maailmanlaajuiseen finanssikriisiin. Ole mainitsee finanssikriisin ja Islannin talousongelmat, kun hän spekuloi miksi islantilaiset haluaisivat tulivuorensa purkautuvan ja syöksevän savua velkojiensa kiusaksi. Islannin talousongelmat olivat radio-ohjelman lähetyksen aikaan keskeinen uutisaihe, ja Ole olettaa, että myös juontajakollega ja radion kuuntelijat tuntevat aiheen. Talousongelmat eivät ole keskustelun keskeinen puheenaihe vaan lähinnä taustatietoa.

(10) [ízü 22.4.2010]

O: dat lea, vuosttažin mun oainnat jurddašan Islánda mot dat lea, se olla.3sg ensinnäkin 1sG katsos ajatella.1sG Islanti miten se olla.3sG mayyel dan, dát go l(e)i miebtá máilmmi dát rubtaváttisvuodat, jälkeen se.GA dát kun olla.PRET.3sG ympäri maailma.GA dát.PL rahaongelmat.PL leat leamaś, de oainnat Islánda, dat lea bui hui hirbmat olu olla.3PL olla.PART.PRF niin katsos Islanti se olla.3sg hyvin hyvin hirveän paljon ruda velggolas, - raha.GA velallinen 'se on, ensinnäkin katsos ajattelen Islantia miten se on, sen jälkeen, tämä kun oli ympäri maailmaa näitä talousongelmia, on ollut, niin Islanti katsos, se on hirveän paljon rahaa velkaa, - -’

Toisessa esimerkissä dát-tarkenteisella lausekkeella viitataan tekstiviestimahdollisuuteen, jolla kuuntelijat voivat osallistua kilpailuun. Juontajat ovat edellä esitelleet senkertaisen kilpailun ja kertovat sitten miten kilpailuun voi osallistua. Ensimmäiseksi
Ailo mainitsee, että kilpailuun voi osallistua lähettämällä tekstiviestin. Tekstiviestimahdollisuuteen hän viittaa lausekkeella dát dá beakkán teakstadiehtuvejolašvuohta 'tämä kuuluisa tekstiviestimahdollisuus'. 
(11) [Dáppe ruovttus 5.3.2010]

A: jo, munnos lea diedusge dát dá beakkán teakstadiehtuvejolašvuohta

joo 2DU.LOK olla.3sG tietenkin dát tässä kuuluisa tekstiviestimahdollisuus

lea jadalle lea, cálát álggos--

olla.3sg ja silloin olla.3sg kirjoittaa.2sG aluksi

'joo, meillä on tietenkin tämä kuuluisa tekstiviestimahdollisuus ja silloin on, kirjoitat aluksi - -'

Juontaja siis olettaa tekstiviestimahdollisuuden tunnetuksi. Samalla dát-pronomini nostaa tarkoitteen fokukseen, ja kuulijat saavat kuulla kilpailun koodin ja numeron, johon tekstiviesti tulee lähettää. Straussin (2002) mukaan proksimaalista pronominia käyttäessään puhuja viestii kuulijalleen, että nyt tulee tärkeä asia. Dát-pronominia vahvistaa vielä jäljessä tuleva samakantainen adverbi dá, joka perinteisesti voi esiintyä pronominin edellä dá dát (Nickel \& Sammallahti, 2011, s. 119). Nähdäkseni pronominin ja sitä vahvistavan adverbin järjestyksen taustalla saattaa vaikuttaa norja, jossa järjestys on den her/denne her.

\section{POHDINTA}

Olen tarkastellut saamen adnominaalisten demonstratiivipronominien, erityisesti pronominien diet ja dát endoforista käyttöä nuorten radiokeskusteluissa. Aiemmin saamen demonstratiivipronomineja on kuvattu lähinnä niiden spatiaalisten ominaisuuksien pohjalta. Lisäksi dat-pronominista on sanottu, että se voi viitata johonkin, joka on juuri mainittu tai joka on yleisesti tunnettu tai josta ollaan sanomassa enemmän. Diet-pronominista puolestaan on mainittu, että se voi myös viitata johonkin, jonka keskustelukumppani on sanonut.

Vaikka yleisin endoforinen pronomini on anaforinen dat, niin myös diet ja dát -pronomineilla voidaan viitata diskurssin sisällä. Tutkimuksessa tuli esille, että diet-pronominilla viitataan radiokeskusteluissa erityisesti tarkoitteisiin, jotka on edellä kuultu, kuten musiikkikappaleisiin ja nauhoitetuissa haastatteluissa kuultuihin henkilöreferentteihin. Diet-tarkenteisella lausekkeilla viitataan myös aiemmin mainittuihin tarkoitteisiin. Kun tarkoite on mainittu edellä, diet-pronominin tilalla voisi usein olla myös dat. Dietpronominin käyttö antaa kuitenkin usein vaikutelman, että viitataan ikään kuin jossain muualla olevaan tai olleeseen yhteyteen: tilanteeseen, keskusteluun tai kokemukseen. Kuten aiemmissakin tutkimuksissa on todettu, diet-pronominilla viitataan usein myös siihen, mitä keskustelukumppani on sanonut. Adnominaalisella diet-pronominilla voidaan viitata myös tarkoitteisiin, joita ei ole aiemmin mainittu, mutta joiden tunnistaminen perustuu keskustelijoiden yhteiseen kokemukseen tai yhteiseksi oletettuun tietoon. Diet + NP ei esiinny aineistossa viittamassa eteenpäin. Tämä vahvistaa käsitystä siitä, että endoforisessa käytössä diet-pronomini on ennen kaikkea anaforinen pronomini. Sen sijaan sekä dat- että dát-pronomini viittaavat myös eteenpäin.

Dát-tarkenteisella nominilausekkeella viitataan aiemmin mainittuihin referentteihin. Nämä ovat keskustelussa keskeisiä tarkoitteita tai teemoja, ja niihin viittaaminen dát + NP:lla nostaa tarkoitteen fokukseen. Adnominaalinen dát on yleisin pronomini kataforisessa käytössä. Dát + NP:tä ei juurikaan käytetä ensimaininnoissa viittaamaan tarkoitteisiin, joiden voi olettaa olevan tuttuja keskustelijoille aiemmasta yhteydestä. Adnominaalista dát-pronominia voisi luonnehtia fokusoivaksi pronominiksi. Kokonai- 
suudessaan tämän tutkimuksen pronominien käyttöä voi kuvata seuraavasti: dát on 'hyvin puheenalainen/fokuksessa', dat 'neutraalisti edellä mainittu' ja diet 'edellä mainittu, josta on ollut puhetta/puhekumppanin mainitsema/jossain muualla esiintyvä.

Saamen demonstratiivipronominien määrä poikkeaa suomen kielestä: saamessa pronomineja on viisi, suomessa kolme. Saamen dat ja suomen se neutraaleina anaforisina pronomineina lankeavat kutakuinkin yksiin merkitykseltään ja käytöltään, kuten myös saamen dát ja duot sekä suomen tämä ja tuo. Saamen diet-pronominille ei ole suomessa suoranaista vastinetta, vaan usein sitä vastaa se, mutta myös tuo. Kun saamessa viitataan esimerkiksi edellä kuultuun musiikkikappaleeseen tai puhekumppanin sanomaan asiaan diet-pronominilla, olisi suomessa vastaavissa tapauksissa tuo luonteva. Musiikkikappaleeseen viittaamista esittelin analyysiosiossa, mutta jälkimmäistä tapausta voisi havainnollistaa seuraavalla esimerkillä: Jos Anne kertoo Lailalle, että heidän yhteinen ystävänsä Lasse on muuttamassa Koutokeinoon, ja Laila vastaa kuulemaansa sanomalla diet ii leat duobta ('se/tuo ei ole totta'), on se ymmärrettävissä niin, että Lailan viittaus kohdistuu Annen sanomiseen, 'tuo mitä sinä sanot' ei ole totta. Suomessa vastaavassa tilanteessa esiintyisi tuo. Jos Laila käyttäisi dat-pronominia (dat ii leat duobta'se ei ole totta'), niin se tarkoittaisi ainoastaan, että Laila ei usko väitettä todeksi, ilman viittausta siihen, että kyseessä on juuri Annen sanoma asia.

Olen tarkastellut tässä tutkimuksessa saamen demonstratiivipronomineja ja rajannut tarkastelun koskemaan niiden adnominaalista ja endoforista käyttöä. Tutkimusaineisto pohdintoineen valaisee saamen demonstratiivien käyttöä nykypuhekielessä ja antaa näin lisätietoa suomalais-ugrilaisten kielten demonstratiiveista. Saamen demonstratiiveja on tutkittu kovin vähän ja tutkittavaa on edelleen runsaasti. Esimerkiksi pronominien endoforisen käytön tarkastelu olisi luontevaa laajentaa koskemaan myös itsenäisiä pronominiesiintymiä. Edelleen olisi mielenkiintoista tarkastella lähemmin rakenteita, joissa adnominaaliset demonstratiivipronominit esiintyvät.

\section{LÄHTEET}

Abondolo, D. (1998). Introduction. Teoksessa D. Abondolo (toim.), The Uralic languages (s. 1-42). London: Routledge.

Bock, K. \& Griffin, Z. (2000). The persistence of structural priming: Transient activation or implicit learning? Journal of Experimental Psychology: General 129, 177-192.

Diessel, H. (1999). Demonstratives. Form, function, and grammaticalization. Amsterdam/Philadelphia: John Benjamins.

Diessel, H. (2006). Demonstratives, joint attention, and the emergence of grammar. Cognitive Linguistics, 17-4, 463-489.

Diessel, H. (2012). Deixis and demonstratives. Teoksessa C. Maienborn, K. von Heusinger \& P. Portner (toim.), Semantics. An international handbook of natural language meaning (s. 1-25). Berlin: de Gruyter Mouton.

Diessel, H. (2013). Distance contrasts in demonstratives. Teoksessa M.S. Dryer \& M. Haspelmath (toim.), The world atlas of language structures online. Leipzig: Max Planck Institute for Evolutionary Anthropology. Verkkoversio. Haettu 3.1.2018 osoitteesta http://wals.info/ chapter/41

Etelämäki, M. (2006). Toiminta ja tarkoitus. Tutkimus suomen kielen pronominista tämä. Helsinki: Suomalaisen Kirjallisuuden Seura.

Fillmore, C.J. (1997). Lectures on deixis. Stanford: CLSI Publications.

Guttorm, O. (2015). Davvisámegiela adnominála dat-demonstratiivadeterminánttas maiddái definihtta artihkalin? Sámi dieđalaš áigećála, 2/2015, 7-31.

Guttorm, O. (2009). Adnominála demonstratiivapronomenat muhtin davvisámegiel teavsttain. Teoksessa J. Ijäs \& N.Ø. Helander (toim.), Sábkavuoruin sábkan. Sámegiela ja sámi girjjálašvuoda muhtin áigeguovdilis 
dutkanfáttát (s. 114-125). Guovdageaidnu: Sámi allaskuvla.

Guttorm, V. (1994). Pronomendeterminatiiva mearusin. Teoksessa V. Guttorm, N. Ø. Helander \& K. Kemi (toim.), Giellaćállosat II (s. 1-16). Guovdageaidnu: Sámi instituhtta.

Halliday, M.A.K. \& Hasan, R. (1976). Cohesion in English. London: Longman.

Himmelmann, N.P. (1996). Demonstratives in narrative discourse. A taxonomy of universal uses. Teoksessa B. Fox (toim.), Studies in anaphora (s. 205-254). Amsterdam: John Benjamins.

Himmelmann, N.P. (1997). Deiktikon, Artikel, Nominalphrase: Zur Emergenz syntaktischer Struktur. Tübingen: Niemeyer.

Juvonen, P. (2000). Grammaticalizing the definite article. Astudy of definite adnominal determiners in a genre of spoken Finnish. Stockholm: Stockholm University, Department of linguistics.

Kilpimaa, O. (2002). Dat-determinánttalaš nomengihpuid definihttavuohta. Guovdageaidnu: Sámi Instituhtta.

Kirsner, R. (1990). From meaning to message in two theories: Cognitive and Saussurean views of the Modern Dutch demonstratives. Teoksessa R.A. Geiger \& B. Rudzuka-Ostyn (toim.), Conceptualizations and mental processing in language: A collection of papers from the Duisburg symposium on cognitive linguistics (s. 81-114). Berlin: Mouton de Gruyter.

Larjavaara, M. (1985). Suomen demonstratiivisysteemin rakenne. - Sananjalka 27, 15-31.

Larjavaara, M. (1986). Itämerensuomen demonstratiivit I. Karjala, aunus, lyydi ja vepsä. Helsinki: Suomalaisen Kirjallisuuden Seura.

Larjavaara, M. (1990). Suomen deiksis. Helsinki: Suomalaisen Kirjallisuuden Seura.

Laury, R. (1997). Demonstratives in interaction. The emergence of a definite article in Finnish. Amsterdam: John Benjamins.

Levinson, S.C. (1983). Pragmatics. Cambridge: Cambridge University Press.

Lyons, J. (1977). Semantics. (Vol. 1-2). Cambridge: Cambridge University Press.

Länsman, H. (2009). "Ja vuoi dan stákku dan olmmošriebus.” Demonstrativapronomeniid geavahus Hans Aslak Guttorm girjiin. Saamen kielen pro gradu -tutkielma. Oulun yliopisto, Giellagas-instituutti.

Nickel, K.P. \& Sammallahti, P. (2011). Samisk grammatikk. Oslo: Universitetsforlaget.

Nielsen, K. (1979). Larebok i lappisk (samisk). I. Grammatikk. (1. painos 1926-29). Oslo: Universitetsforlaget.

Pajusalu, R. (2015). Võro demonstratives. Changing or dissappearing? - Eesti ja soome-ugrikeeleteaduse ajakiri. Journal of Estonian and FinnoUgric Linguistics, 6-2, 167-190.

Priiki, K. (2014). Kaakkois-Satakunnan henkilöviitteiset hän, se, tää ja toi subjekteina. Sananjalka, 56, 86-107.

Priiki, K. (2017). Hän, se, tää vai toi? Vuorovaikutussosiolingvistinen tutkimus henkilöviittauksista Kaakkois-Satakunnan nykypubekielessä. Turun yliopiston julkaisuja, Sarja C, Scripta lingua Fennica edita. Turku: Turun yliopisto.

Reile, M. (2015). Space and demonstratives: An experiment with Estonian exophoric demonstratives. - Eesti ja soome-ugri keeleteaduse ajakiri. Journal of Estonian and Finno-Ugric Linguistics, 6-2, 137-165.

Sammallahti, P. (1998). The Saami languages. Kárášjohka: Davvi Girji.

Sammallahti, P. (2005). Láidehus sámegiela cealkkaoahpa dutkamii. Kárášjohka: Davvi Girji.

Seppänen, E.-L. (1998). Läsnäolon pronominit. Tämä, tuo, se ja hän viittaamassa keskustelun osallistujaan. Helsinki: Suomalaisen Kirjallisuuden Seura.

Strauss, S. (2002). This, that, and it in spoken American English: A demonstrative system of gradient focus. Language Sciences, 24, 131-152.

Tammekänd, L. (2015). Demonstratives in Võro and Estonian oral narratives. - Eesti ja soomeugrikeeleteaduse ajakiri. Journal of Estonian and Finno-Ugric Linguistics, 6-2, 191-216.

VISK = A. Hakulinen \& M. Vilkuna \& R. Korhonen \& V. Koivisto \& T.R. Heinonen \& I. Alho (2004). Iso suomen kielioppi. Helsinki: Suomalaisen Kirjallisuuden Seura. Verkkoversio. Haettu 18.1.2018 osoitteesta http://scripta.kotus.fi/ visk/etusivu.php 


\section{ADNOMINAL DEMONSTRATIVE PRONOUNS IN NORTH SAAMI YOUTH RADIO PROGRAMMES}

Outi Guttorm, Sámi University of Applied Sciences

This article discusses the endophoric use of the adnominal demonstrative pronouns, especially dát 'this', and diet 'it, the one near you', in North Saami spoken by young adults. The aim is to show how demonstrative pronouns are used, and to what they refer in youth radio conversation, a setting in which referring to specific visible referents is not the first priority. In addition, the differences between pronouns as well as their functions will also be discussed. The data used in the study has been collected from Saami youth programmes aired on the Norwegian Broadcasting Company, NRK. In these programmes, the following demonstratives: dat 'that, it', diet 'it, the one near you' and dát 'this', occur as endophoric pronouns, while the most common anaphoric pronoun is dat. In radio conversation, diet refers specifically to something that has been previously heard. It also refers to a referent which appears in another context, or to a subject introduced by one of the participants. The pronoun dat, on the other hand, brings the referent into particular focus, as well as being the most common cataphoric pronoun. The study reinforces and refines our earlier understanding of the use and meaning of the North Saami demonstrative pronouns.

Keywords: demonstrative pronoun, North Saami, Saami language, spoken language 